\title{
Examining gender role attitude as a moderator of personality, social support, and childcare responsibilities in women's work-life balance
}

\author{
Abdul Rahman Shaleh, ${ }^{1 *}$ Putri Nuraini ${ }^{1}$ \\ ${ }^{1}$ Faculty of Psychology, Universitas Islam Negeri Syarif Hidayatullah Jakarta, Tangerang Selatan - Indonesia
}

\begin{abstract}
The participation of women in the workforce creates challenges and problems. Those with various roles in their lives must be good at playing and balancing these successfully. This study focuses on the work-life balance factor by exploring the predictor factors including personality, family social support, and childcare responsibilities, as moderated by gender role attitude. A work/ nonwork interference and enhancement scale, mini-IPIP, gender role beliefs scale, and social support scale were developed for the data collection. A sample of 220 married female workers was identified using purposive sampling. The data analysis, which used multiple regression and a modgraph, shows a significant effect of personality, social support, and childcare responsibilities on the work-life balance moderated by gender role attitude. Four independent variables with significant influence are neuroticism, openness to experiencing family support, gender role attitude and there is a moderating effect on neuroticism and family support. The implication is the need to provide a comfortable work environment and arrangement of work patterns so that women's work-life balance can be achieved positively.
\end{abstract}

Keywords: gender role attitudes; number of children; personality; social support; work-life balance

\begin{abstract}
Abstrak: Partisipasi perempuan dalam dunia kerja menciptakan tantangan dan masalah tersendiri. Perempuan dengan berbagai peran kehidupannya mesti pandai menjalankan peran dan menyeimbangkannya. Penelitian ini fokus pada faktor keseimbangan kerja-kehidupan dengan mengeksplorasi faktor prediktornya mencakup kepribadian, dukungan sosial keluarga, dan childcare responsibilities dimoderatori oleh gender role attitude. Skala Work/Nonwork Interference and Enhancement, Mini-IPIP, Gender Role Beliefs Scale dan skala social support dikembangkan untuk pengumpulan data. Sampel berjumlah 220 pekerja perempuan yang telah menikah diambil secara purposive sampling. Analisis data menggunakan multiple regression dan modgraph memperlihatkan pengaruh yang signifikan personality, social support, dan childcare responsibilities terhadap work-life balance dimoderatori gender role attitude. Empat variabel independen yang pengaruhnya signifikan meliputi neurocitism, opennes to experience family support, gender role attitude dan terdapat efek moderasi pada variabel neurocitism dan variabel dukungan keluarga. Implikasinya adalah perlunya menghadirkan lingkungan kerja dan pengaturan pola pekerjaan yang nyaman agar keseimbangan kerja-kehidupan perempuan dapat dilakukan secara positif.
\end{abstract}

Kata Kunci: sikap peran gender; jumlah anak; kepribadian; dukungan sosial; worklife balance

\footnotetext{
*Corresponding Author: Abdul Rahman Shaleh (abd.rahman.shaleh@uinjkt.ac.id), Faculty of Psychology UIN Syarif Hidayatullah Jakarta, Jl. Kertamukti 5 Cirendeu Ciputat Tangerang Selatan 15419-Indonesia.
} 


\section{Introduction}

The participation of women in the workforce continues to increase. Nowadays, women not only play a role in the domestic sphere, but also play an active role in fulfilling in public areas. Data from the World Bank (2021) shows that 53\% of Indonesian women participate in the workforce. Data from the Indonesian Manpower Agency reported on the Kementerian Pemberdayaan Perempuan dan Anak website (2018) also shows as many as $55.50 \%$ of women, equivalent to 69.850 million, who participate in the workforce. This figure will continue to grow, considering that currently women have educational and employment opportunities equal to men. However, on the other hand the presence of women in the workforce creates its own challenges and problems, especially for married women workers.

These women often experience role conflict. They not only have a role to play at work, but also have a role at home. This is especially the case in eastern culture, where the patriarchy places women in domestic roles, making them closely involved in household responsibilities (Shaleh, 2003). Furthermore, Duxbury and Higgins (2018) state that women's participation in the workforce places a double burden on them as women. On one hand, they are committed to their work just as men are, but at the same time they must also prioritize their role in the family as housewives. Such conditions sometimes make it difficult for women to balance their responsibilities as workers and housewives. Working women therefore experience many challenges and often feel as if they have failed to be good mothers because they are busy working. Other problems that arise are lack of sleep, often being late for work, and lack of time for themselves, or "me time" (see for example Dilawati et al. (2021), Gora (2016), Kurniawan (2021), Dari and Fikri (2021).

The results of research by Atiq et al. (2018) shows that when individuals spend more time at work, their partners and children will suffer, as will their functions and obligations in the family. In addition, time spent with the family will be less, which sometimes creates problems, and may lead to serious marital problems resulting in divorce (Atiq et al., 2018). On the other hand, if individuals spend more time on their personal lives, work could be neglected and women may eventually have to leave their jobs and careers (Bell et al., 2012; Bryant \& Constantine, 2006). Research conducted by the International Labor Organization (2016) shows that one of the main problems for women is balancing their work and life outside of work. In addition, according to some researchers, women find it more difficult to manage the balance between personal and professional responsibilities than men (Atiq et al., 2018; Favero \& Heath, 2012).

In fact, those who work today emphasize the importance of balancing their personal and work life, especially the the millennial generation. However, the balance between work and personal life achieved remains lower than what is desirable (Meenakshi et al., 2013).To overcome this problem, it is important for female workers to balance their work and personal lives; in psychological studies, this is known as the work-life balance. In this study, the definition of work-life balance by Fisher et al. (2009) is used. According to them, it is a process undertaken by individuals to divide their time between work and activities outside of work, in which there are disturbances and improvements that include four aspects. The 
four aspects are time, behavior, tension, and energy to achieve job satisfaction and personal life. This definition is used because it is considered more comprehensive in explaining the work-life balance.

Such a balance has both positive and negative impacts on individuals and organizations. Overall, individuals with a good work-life balance have a better quality of life (Greenhaus et al., 2008). Haar et al. (2014) state that this balance is a key factor in increasing life satisfaction and mental health in various cultures. In addition, the work-life balance has been shown to increase job satisfaction. Individuals with a positive work-life balance have high psychosocial well-being (Yang et al., 2018). An environment that allows employees to achieve awork-life balancewill strengthen employee loyalty and productivity (Meenakshi et al., 2013).

On the other hand, if individuals have a poor work-life balance, this will harm the health and well-being of employees and organizational performance (Beauregard \& Henry, 2009; Shaffer et al., 2016). If organizations do not develop strategies to balance work and personal life, they are more vulnerable to losing talented workers (Haar et al., 2012). In addition, individuals who do not have a work-life balance experience higher stress, which can lead to greater turnover among employees (Kumara \& Fasana, 2018; Smith \& Gardner, 2007). The results of research by Lunau et al. (2014) show that individuals who have a poorwork-life balance may have more health problems.

Several factors affect the work-life balance, both internal and external. In this study, the authors examine personality factors related to internal aspects. According to Kundnani and Mehta (2014), personality affects the perception of balance in each individual. Different personality traits allow individuals to cope with the work-life balance in different ways (Crooker et al., 2002). In the scheme of the five personality types, each person displays neuroticism, conscientiousness, agreeableness, openness, and extraversion. Those with high neuroticism tend to experience negative feelings of anger, anxiety, depression, fear, guilt, impulsivity, and sadness, among others. The result is positively close to role conflict, excessive stress at home and work those trigger work-life imbalances.

Meanwhile, people may have high conscientiousness because they like competence and regularity, and like to plan coping strategies well to reduce the possibility of conflict in balancing each role they play. Therefore, conscientiousness is negatively related to role conflict and can increase the ability to balance one's work and life.In contrast, people with agreeableness attempt to compromise and show sympathy, so they are easily "crushed" as they always try to please people. Judging from these characteristics, people with high agreeableness appear to be those with high egocentrism and tend to have low role conflict and a positive work-life balance. In addition, openness is associated with being sensitive to beauty, attention, with ideas and independence in making decisions and judgments, as well as intellectual development and values. With this trait, people with high openness tend to be open to change. Therefore, such people are negatively associated with role conflict and favor positive work-life balance situations. In line with this, those with the extraversion dimension tend to show an open, warm, optimistic, and assertive social attitude. With this trait, highly extravert people will also have a negative relationship with role conflict and positively support the fulfillment of a work-life balance. 
In addition, social support from external factors is also a resource that is considered to be able to contribute to the work-life balance (Schieman et al., 2009; Thompson \& Prottas, 2006). Social support is very important in increasing the ability to create a work-life balance by reducing conflict between one's work and personal life by reducing time demands and stress (Marcinkus et al., 2007). Family support in particular, referred to as natural support, is considered to be the best option when individuals experience urgency and need help (Dolan, 2008). Social support from spouses, parents, or in-laws makes it easy for working women to have a good work-life balance (Gupta, 2016).

However, the views on and treatment of women in the public sphere remain paradoxical (Gora, 2016; Kurniawan, 2021). The role of women is still attached to domestic stereotypes based on traditional cultural constructs (Adachi, 2018; Smith-Hefner, 2019; Watkins, 2015). In this view, parenting and other domestic roles are predominantly the role of women, including in the Indonesian context (Olivetti et al., 2020). Society chooses appropriate roles for men and women, known as gender roles. These are the result of interactions between individuals and their environment and provide them with ideas of how to behave according to gender (Blackstone, 2003). This role identity is categorized into liberal/modern and traditional (Adachi, 2018).

Michalos (2014) states thatgender role attitude is defined as a perspective individuals believe in concerning men's and women's roles in society. Individuals are considered to have traditional gender role attitudes when they agree that men act as breadwinners and women act as housewives. On the other hand, if they disagree with such a division of roles and instead want an equal division of responsibilities, they are considered to have an egalitarian or modern gender role attitude. With their perceived gender role identity, married women workers tend to feel that their home and work lives are intermingled (Olivetti et al., 2020). As a result, the work-life relationship becomes unbalanced. According to Adachi (2018), individuals with a modern/liberal gender role attitude have a more balanced time allocation plan for their work and personal lives.

In relation to this, under social pressure one must developpersonal gender roles in the enculturation process (Kurpisz et al., 2016). This has to do with the type of personality that one has. Such personality traits influence individuals in managing or coping with their work and personal lives, including responding to pressures in their social roles and balancing their work and lives (Pandey et al., 2018). Referring to this view, individuals with high neuroticism, consciousness, and agreeableness will follow traditional roles, with a submissive attitude to culture, and they will tend to experience pressure. At the same time, those with openness and extraversion will try to come to terms with being open and managing their personal and work lives. In addition, as part of social construction, gender roles are closely related to how family values are seen concretely in supporting women as wives.

Based on the above discussion, there is a need for research on the work-life balance of married millennial female workers. Moyer and Hedden (2020) found that there are differences in considering work patterns and traditional roles in modern millennial families. Moreover, (Olivetti et al., 2020) found that women still have difficulties 
in responding to their domestic and public roles and balancing their work and lives. Smith-Hefner (2007), despite observing changes in Javanese women, still believes that they still have a traditional attitude towards their gender roles. This of course will affect their work-life balance.

The question then is whether the millennial family so that women can achieve success in their careers without neglecting the duties and responsibilities of their role as women. The focus of this research is to examine whether personality, social support, and childcare responsibilities have an influence on the work-life balance of women, with gender-role attitudes as moderators. In line with this aim, this research is formulated based on the hypothesis that "there is a relationship between personality, social support and childcare responsibilities which is moderated by gender role attitude towards women's work-life balance".

\section{Methods}

\section{Research Approach}

The quantitative research method is adopted, which is intended to explore the influence of personality, social support, and childcare responsibilities, moderated by gender role attitude, on women's work-life balance.

\section{Population and Sample}

The study population comprised female workers who were married and had worked for more than 1 year. The sample included was 220 female workers who were selected using the nonprobability sampling technique and purposive sampling. The sample criteria were married female workers who were born between 1980 and 2000. The study did not differentiate between the number of children because

\section{Data Collection Instrument}

The data were collected through Google Forms by developing five measuring tools related to the research. Work-life balance was measured by adapting the Work/Nonwork Interference and Enhancement Scale developed by Fisher et al. (2009), which consists of 17 items. The instrument to measure personality was an adaptation of the Mini-International Personality Item Pool Five-factor Model developed by Donnellan (2006), consisting of 20 items. Furthermore, measurement of social support was adapted from the theory of sources of support of Zimet et al. (1988) and the theory of the type of social support of House (1981). In addition, the instrument used to measure gender role attitudes was the Gender Role Beliefs Scale (GRBS) developed by Brown and Gladstone (2012), consisting of 10 items. All the items were tested for validity using confirmatory factor analysis (CFA). Based on this, it was found that the Work/Nonwork Interference and Enhancement scale was declared fit, with chi-square $=125,794$, $\mathrm{df}=106$, P-value $=0.0921$, and RMSEA $=0.029$. The Mini- International Personality Item Pool Five-Factor Scale Model was also fit, with chisquare $=134,390, \mathrm{df}=110, \mathrm{P}$-value $=0.0570$, and RMSEA $=0.032$. The Social Support Scale was fit, with chi-square $=32.031, \mathrm{df}=24$, P-value $=$ 0.1262 , and RMSEA $=0.039$. Finally, the Gender Role Belief scale was fit, with chi-square $=22,187$, $\mathrm{df}=24, \mathrm{P}$-value $=0.5681$, and RMSEA $=0.000$. Therefore, all the measuring instruments were deemed to have valid and unidimensional items.

\section{Data analysis}

The data were analyzed using multiple regression analysis and a modgraph to develop a description of the interaction between the 
independent variable, the moderator variable, and the dependent variable.

\section{Results}

The results show that the obtained $\mathrm{R}$ square of or was $31.3 \%$. This means that the variation of work-life balance is explained by personality, social support and childcare responsibilities at the level of $31.3 \%$, while the remaining $68.7 \%$ is influenced by other variables outside this study. Furthermore, the authors conducted an F test to analyze the effect of the overall independent variable on work-life balance. This test obtained an F of 10.610, with sig .00 (sig < .05). Therefore, the null hypothesis which states that there is no significant influence between personality, social support, and childcare responsibilities on worklife balance is rejected, meaning that there are a jointly significant influence of personality, social support, and childcare responsibilities on worklife balance.

We then considered the regression coefficient, or the value of the weight of influence. If the value of sig. $<.05$, the regression coefficient is significant, which means that the independent variable has a significant impact on work-life balance. The level of the regression coefficient of each independent variable on work-life balance can be seen in the Rsquare change scores. It was found that out of the nine variables, only three significantly affected the work-life balance, namely neuroticism, openness to experience, and family support. The other six variables had no significant effect on work-life balance.

Furthermore, the authors conducted a linear regression analysis between the gender role attitude variable (the moderator variable) andwork-life balance. If sig > .05, then the regression coefficient is significant, meaning that the gender role attitude variable has a significant influence on work-life balance. The following is the level of the regression coefficient of the moderator variable on work-life balance.

Based on Table 2, it can be seen that gender role attitudeas a moderating variable has a significant direct effect on work-life balance.

Table 1

Result Summary

\begin{tabular}{|c|c|c|c|c|c|c|}
\hline Model & $\mathrm{R}$ & R-Square/B & $\mathrm{T}$ & Sig & $\begin{array}{c}\text { R Square } \\
\text { Change }\end{array}$ & $\begin{array}{c}\text { Sig. F } \\
\text { Change }\end{array}$ \\
\hline ALL & $.559 a$ & .283 & 10.61 & $.000^{\mathrm{b}}$ & & \\
\hline TS_EX & .237 & .052 & 0.701 & .484 & .056 & $.000^{*}$ \\
\hline TS_AGRA & .239 & .047 & 0.631 & .529 & .001 & .58 \\
\hline TS_CONS & .366 & .099 & 1.345 & .18 & .077 & $.000^{*}$ \\
\hline TS_NEU & .47 & .334 & 5.094 & $.000^{*}$ & .087 & $.000^{*}$ \\
\hline TS_OPEN & .495 & -.187 & -3.001 & $.003^{*}$ & .024 & $.010^{*}$ \\
\hline TS_KLRG & .544 & .224 & 2.385 & $.018^{*}$ & .051 & $.000^{*}$ \\
\hline TS_TMN & .548 & -.076 & -1.053 & .293 & .005 & 0.22 \\
\hline TS_SUAMI & .549 & .041 & 0.479 & .632 & .001 & .665 \\
\hline JMLH_ANAK & .559 & -1.109 & -1.855 & .065 & .011 & .065 \\
\hline TS_GRA & & .186 & 2.792 & .006 & & \\
\hline
\end{tabular}


Table 2

Summary of Moderator Effects

\begin{tabular}{cccc}
\hline \multirow{2}{*}{ Model } & $\begin{array}{c}\text { Unstandarized } \\
\text { coefficients }\end{array}$ & $\mathrm{T}$ & Sig. \\
\cline { 2 - 3 } & $\mathrm{B}$ & & .000 \\
(Constant) & 40.710 & 11.998 & .006 \\
TS_GRA & .186 & 2.792 & .265 \\
TS_NEU & -.380 & -1.118 & .061 \\
TS_GRA & -.578 & -1.881 & .020 \\
NEU_GRA & .014 & 2.348 & .151 \\
TS_OPEN & -.438 & -1.442 & .977 \\
TS_GRA & .008 & 0.029 & .559 \\
OPEN_GRA & .003 & 0.586 & .048 \\
TS_KLRG & -.459 & -1.991 & .000 \\
TS_GRA & -.789 & -3.880 & .000 \\
KLGR_GRA & .016 & 3.891 & \\
\hline
\end{tabular}

It can therefore be concluded that the variable family supportX gender role attitude is significant on work-life balance, meaning that the effect of family support on work-life balance depends ongender role attitude. The variable proved to have a significant effect and was analyzed further using a modgraph to observe the interaction between the variables. The interaction pattern of family supportwith gender role attitude is a synergistic interaction, meaning that a high gender role attitude causes the influence of family support on work-life balance to strengthen. At the same time, along with the weakening of gender role attitude, theinfluence of family support on work-life balance weakens

\section{Discussion}

The results show that in general the women workers in the study have a high level of work-life balance, which indicates that the majority of respondents can balance their work and personal life. The respondents were in the age range of 20 40 , known as the millennial generation. The results of the study are in line with the Central
Statistics Agency report on the Kementerian Pemberdayaan Perempuan dan Anak (2018), which states that the millennial generation tends to be more concerned about work-life balance than other generations.

As previously explained, the neuroticism dimension of the big-five personality has a significant positive effect on work-life balance, meaning that the higher the neuroticismvalue of the individual, the higher the work-life balance. Individuals with neurotic personalities are often associated with anxiety, and the results of this study indicate that the more anxious individuals are, the easier it is to achievea work-life balance. Based on the study data, it appears that their anxiety is controlled anxiety, because in general the respondents have a low neuroticism score.

This finding is interesting in light of the general view of neuroticism. What can explain this is that there is pressure on women, as represented by the subjects in the study, to always try to be rational and control their anxiety. This can also be seen in the case of female online motorcycle taxi 
workers (Kurniawan, 2021), who continue to struggle in the midst of the harshness of life, even though they are filled with concerns for their safety.Women's masculinity is shown through their soft side (Siregar et al., 2021) to still earn a living for their families (Gora, 2016; Sari \& Zufar, 2021). This struggle is needed to maintain the resilience of their family (Dilawati etal., 2021).

This is in line with the explanation that anxiety is a normal feeling that one day we can experience. The fact is that anxiety is often a good thing, as it reminds us of things we might need to worry about. It helps individuals to evaluate potential threats and to respond to them in an appropriate way (Krisberg, 2014). Clinical psychologists explain that anxiety is beneficial at the right level and condition, and that we need it to encourage us to focus and think about solutions to the challenges we face; however, when it is excessive it will have a bad impact (Krisberg, 2014). In line with the Mental Health Foundation (2014), anxiety helps individuals to evaluate potential dangers by focusing their attention on issues that may be harmful. Based on this, it can be said that anxiety within reasonable limits and in the right situation can actually help individuals to better prepare themselves in achieving a worklife balance.

The openness to experience dimension of the big-five personality has a significant negative effect on work-life balance, meaning that the higher an individual's openness to experience, the lower the work-life balance. This is in line with the results of research conducted by Kundnani and Mehta (2014), which shows that open-minded individuals display higher and lower levels of stress in balancing their personal and work lives (see for example Dilawati et al., 2021; Sari \& Zufar, 2021).
Furthermore, the family support dimension of social support has a significant and positive effect on work-life balance, meaning that the higher the individual's family support value, the higher the work-life balance. This is in line with the results of previous research (Atiq et al., 2018; Padma \& Reddy, 2013), which found that family support is significantly related to work-life balance. To be able to create a balance between personal and professional life, women need family support (Edralin, 2013). If they do not receive such support from family members, they will find it difficult to fulfil their obligations.

Furthermore, the gender role attitude variable has a significant effect in a positive direction, meaning that the higher the individual's gender role attitudevalue, the higher the work-life balance. In this study, the results show that in general respondents had a highgender role attitude score, meaning that they had a gender role attitude that tended to be modern. This is in line with research conducted by Adachi (2018), who found that individuals with modern gender role attitudes had a more balanced time allocation plan for work and life.

Gender roles are a set of rules on how a person behaves in society based on gender, and under the pressure of social expectations. All members of society develop their personal gender roles as part of their personality in the process of enculturation (Kurpisz et al., 2016). Therefore, personality traits affect individual attitudes in managing or coping with work and personal life (Pandey et al., 2018).

The study found a synergistic interaction between the variable of neuroticism $x$ gender role attitude towards work-life balance, meaning that a high gender role attitude makes the influence of 
neuroticism on the work-life balance strengthen. Meanwhile, along with the weakening of gender role attitude, the influence of neuroticism on work-life balance also weakens. This finding is interesting, because when individuals have modern gender role attitudes, neuroticism also increases, whereas individuals with high neuroticism tend to be anxious. However, it seems that their anxiety is controlled anxiety. In this study, the respondents generally had low neuroticism scores. According to Rego (in Krisberg, 2014), a clinical psychologist, anxiety is good at the right level and condition, so we need it to encourage us to focus and think about solutions to the challenges we face. This is an interesting finding, because in the subjects studied, anxiety and fear in many ways meet in difficult situations. As a result, the biggest concern about not receiving additional income makes workers overcome and create coping strategies to stay balanced in their gender roles and work-life balance. Anxiety and worry are defeated by the urge to provide for the family (Kurniawan, 2021).

Another variable that interacts with gender role attitude is family support. The results of this study show that there is a synergistic interaction between family support variables and gender role attitude, meaning that a high gender role attitude makes the influence of family support on worklife balance strengthen. At the same time, along with the weakening of gender role attitude, the influence of family support on work-life balance also weakens. The family support provided will be meaningless if the individual still has the attitude of traditional gender roles, because a woman will still feel guilty if she is not able to perform her role properly. According to Najwa Shihab (2019), women whochoose to work outside the home often suffer from anxiety because of the fear of not being able to balance their lives. This concern will make individuals stressed and make it increasingly difficult for them to achieve a work-life balance. On the other hand, individuals who have a modern gender attitude will enjoy performing their roles at work and those in their personal lives, because the ones at home that cannot be done by them can be undertaken by other family members, without constant feelings of guilt, so individuals can easily work together and achieve a work-life balance.

The extraversion dimension of the big-five personality variable was not found to have a significant effect on work-life balance. In this study, the results show that in general, respondents had extraversion scores in the low category. According to McCrae and Costa (1995), thosewith low extraversion scores tend to be quiet, aloof, passive, and lack the ability to express emotions, which will make it difficult for them to achieve a work-life balance.

Furthermore, the agreeableness dimension of the big-five personality variable was not found to have a significant effect on work-life balance. It was found that in general respondents had low agreeableness scores; according to McCrae and Costa (1995), individuals with low such scores are generally suspicious, stingy, unfriendly, irritable, and likely to criticize others. This makes it difficult for them to balance their work and personal life. This is in line with Zakaria and Abdullah's research (2018), which found that an agreeable personality was not related to work-life balance.

Furthermore, the conscientiousness dimension of the big-five personality was not found to have a significant effect on work-life balance. The results show that in general respondents had high conscientiousness scores. According to McCrae and Costa (1995), those with high conscientious- 
ness scores tend to be goal orientated, ambitious, and prioritize tasks. This makes individuals focus too much on one aspect of life, for example work, so they tend to ignore things outside their work. This will certainly make it difficult for them to achieve a work-life balance.

The friend support dimension of the social support variable has no significant effect on worklife balance. The results show that in general respondents had friend support scores in the high category. The support of friends may make husbands feel uncomfortable because they may assume that their wife's friends will be their main confidants, not them. In addition, this may also lead to negative perceptions in husbands, because friends are considered to interfere in marriages, which can lead to quarrels between partners (Fiori et al., 2018). This situation will make it more difficult for individuals to achieve a worklife balance.

The husband support dimension of the social support variable has no significant effect on worklife balance. In general, this has high scores, but the support may not be completely felt because of the limited time that the husband has; all the respondents had husbands who worked. Furthermore, the childcare responsibilities variable has no significant effect on work-life balance. This is in line with the results of a study conducted by Padma and Reddy (2013), who found that childcare responsibilities do not determine a person's work-life balance level.

In relation to attitudes towards the moderating effect of gender roles, it can be stated that the subjects still show traditional attitudes in their gender roles. This is seen from the results of the moderating effect on the interacting variables.

The study found a synergistic interaction between the variables of neuroticism $\mathrm{x}$ gender role attitude and work-life balance, meaning that a high gender role attitude makes the influence of neuroticism on the work-life balance strengthen. At the same time, along with the weakening of gender role attitude, the influence of neuroticism on the work-life balance also weakens. This finding is interesting, because when individuals have modern gender role attitudes, neuroticism also increases, whereas those with high neuroticism tend to be anxious. This anxiety is not always bad; in fact, it can make a person better off and help them avoid dangerous situations. Anxiety encourages us to focus and think about solutions to the challenges we face (Krisberg, 2014), making it easier for individuals to achieve a work-life balance.

Another variable that interacts with gender role attitude is family support. The results of the study show that there is a synergistic interaction between family support variables and gender role attitude, meaning that a high gender role attitude makes the influence of family support on the work-life balance strengthen. At the same time, along with the weakening of gender role attitude, the influence of family support on the work-life balance also weakens. The study results in fact show that the traditional attitude of gender roles leads to more family support in pragmatic matters.

In principle, traditional attitudes decide women's activities in relation to their family; for example, as mothers who are responsible for their children's education and other household chores, such as cleaning and cooking. The development of gender discourse has strengthened the role of women in public services, who are working outside the family. Women who are considered weaker than men may actually be torn between work outside the home and household work (e.g., 
caring for their children and husband) (Wahid \& Lancia, 2018; Wiasti, 2012). Women are therefore seen as weaker and should not be in public for too long; working in public spaces is dangerous for women. Moreover, women cannot be separated from daily activities in the domestic space, as mothers have to take care of the housework. Therefore, if women work in public spaces, it is really an addition to the family work or is done when forced todue to an emergency (Rahmawati et al., 2019; Wahid \& Lancia, 2018; Wiasti, 2012). However, the drive to provide for the family seems to put women in a difficult situation. Women workers try to adopt coping strategies for their gender roles to look modern because they work in public spaces. This is done while managing their anxiety and ensuring family support. At this stage, women appear to be modern and masculine in their gender roles, but eventually become more flexible in these gender roles. In the context of this study, the role of gender is similar to being a good moderator in predicting work-life balance.

\section{Conclusion}

The results of this study indicate that the level of variance in the work-life balance explained by the variables of personality, social support, and childcare responsibilities is $31.3 \%$, but there are many other factors that have not been studied. Therefore, further research is needed to examine other variables that affect the work-life balance, such as emotional intelligence, stress, self-efficacy, work engagement, turnover intention, personality, psychological well-being, perception of support at work, perception of family support, psychological capital, role conflict, gender roles, supervisor support, co-worker support, working hours, family support, organizational support, social media, flexible working arrangements, transformational leadership, social support, workload, and childcare responsibilities. Based on this, office policymakers can also organize work-life balance programs which provide more flexible working hours, create a healthy work environment, provide additional leave, and provide quiet spaces by taking into account the influencing factors and cultural values that also influence them. In addition, they can also provide special counseling programs for workers on how to achieve a work-life balance.

The results of the study also show that there are four dimensions that have a significant influence on work-life balance, namely neuroticism, openness to experience, family support, and gender role attitude. The authors ssuggests that these variables be re-examined in further research by taking into account the motivational factors that exist in the life situations of women workers as issues that should be included in studies.[]

\section{References}

Adachi, T. (2018). Work-family planning and gender role attitudes among youth. International Journal of Adolescence and Youth, 23(1), 52-60. https://doi.org/10.1080/02673843.2016.1269655

Atiq, S., Iqbal, S., \& Rasheed, M. (2018). Work life balance and intention to quit among female workforce. Asia Pacific Journal of Advanced Business and Social Studies, 4(1), 117-126. https://doi.org/10.25275/apjabssv4i1bus12 
Beauregard, T. A., \& Henry, L. C. (2009). Making the link between work-life balance practices and organizational performance. Human Resource Management Review, 19(1), 9-22. https://doi.org/10.1016/j.hrmr.2008.09.001

Bell, A. S., Rajendran, D., \& Theiler, S. (2012). Job stress, wellbeing, work-life balance and work-life conflict among Australian academics. E-Journal of Applied Psychology, 8(1), 25-37. https://doi.org/10.7790/ejap.v8i1.320

Blackstone, A. M. (2003). Gender roles and society. In R. M. Julia, M. L. Richard, \& L. B. Schiamberg (Eds.), Human ecology: An encyclopedia of children, families, communities, and environments (pp. 335338). ABC-CLIO.

Brown, M. J., \& Gladstone, N. (2012). Development of a short version of the Gender Role Beliefs Scale. International Journal of Psychology and Behavioral Sciences, 2(5), 154-158. https://doi.org/10.5923/j.ijpbs.20120205.05

Bryant, R. M., \& Constantine, M. G. (2006). Multiple role balance, job satisfaction, and life satisfaction in women school counselors. Professional School Counseling, 9(4), 265-271. https://doi.org/10.1177/2156759X0500900403

Costa, P. T., McCrae, R. R., \& Kay, G. G. (1995). Persons, places, and personality: Career assessment using the revised NEO personality inventory. Journal of Career Assessment, 3(2), 123-139. https://doi.org/10.1177/106907279500300202

Crooker, K. J., Smith, F. L., \& Tabak, F. (2002). Creating work-life balance: A model of pluralism across life domains. Human Resource Development Review, 1(4), 387-419. https://doi.org/10.1177/1534484302238434

Dilawati, R., Zulaiha, E., \& Huraiani, Y. (2021). Perempuan dan ketahanan keluarga di masa pandemi COVID-19: Studi kasus mantan para pekerja perempuan di kota Bandung. Journal of Society and Development, 1(2), 46-58.

Dolan, P. (2008). Social support, social justice, and social capital: A tentative theoretical triad for community development. Community Development, 39(1), 112-119. https://doi.org/10.1080/ 15575330809489745

Donnellan, M. B., Oswald, F. L., Baird, B. M., \& Lucas, R. E. (2006). The Mini-IPIP Scales: Tiny-yet-effective measures of the Big Five Factors of Personality. Psychological Assessment, 18(2), 192-203. https://doi.org/10.1037/1040-3590.18.2.192

Duxbury, L., \& Higgins, C. (2018). Something's got to give. University of Toronto Press.

Edralin, D. M. (2013). Work and life harmony: An exploratory case study of EntrePinays. DLSU Business and Economics Review, 22(2), 15-36.

Favero, L. W., \& Heath, R. G. (2012). Generational perspectives in the workplace: Interpreting the discourses that constitute women's struggle to balance work and life. Journal of Business Communication, 49(4), 332-356. https://doi.org/10.1177/0021943612456037

Fiori, K. L., Rauer, A. J., Birditt, K. S., Marini, C. M., Jager, J., Brown, E., \& Orbuch, T. L. (2018). “I love you, not your friends": Links between partners' early disapproval of friends and divorce across 16 years. Journal of Social and Personal Relationships, 35(9), 1230-1250. https://doi.org/10.1177/0265407517707061

Fisher, G. G., Bulger, C. A., \& Smith, C. S. (2009). Beyond work and family: A measure of work/nonwork interference and enhancement. Journal of Occupational Health Psychology, 14(4), 441-456. https://doi.org/10.1037/a0016737 
Gora, R. (2016). Representasi perempuan dalam iklan televisi (Studi analisis semiotika iklan Beng Beng versi “Great Date”). Jurnal Semiotika, 10(1), 151-179. https://doi.org/10.30813/s:jk.v10i1.32

Greenhaus, J. H., Callanan, G. A., \& DiRenzo, M. (2008). A boundaryless perspective on careers. In J. Barling \& C. L. Cooper (Eds.), The SAGE handbook of organizational behavior (pp. 277-29). SAGE Publications Inc.

Gupta, S. (2016). A study on 'Work Life Balance' of married women employees teaching in technical institutions of Moradabad region. International Research Journal of Management Sociology \& Humanities, 7(12), 82-89. https://doi.org/10.32804/IRJMSH

Haar, J. M., Roche, M., \& Taylor, D. (2012). Work-family conflict and turnover intentions of indigenous employees: the importance of the whanau/family for Maori. The International Journal of Human Resource Management, 23(12), 2546-2560. https://doi.org/10.1080/09585192.2011.610344

Haar, J. M., Russo, M., Suñe, A., \& Ollier-Malaterre, A. (2014). Outcomes of work-life balance on job satisfaction, life satisfaction and mental health: A study across seven cultures. Journal of Vocational Behavior, 85(3), 361-373. https://doi.org/10.1016/j.jvb.2014.08.010

House, J. S. (1981). Work stress and social support. Addison-Wesley Pub. Co.

ILO. (2016). Women at work: Trends. International Labour Office.

Kementerian Pemberdayaan Perempuan dan Anak. (2018). Statistik gender tematik: Profil generasi milenial Indonesia.

Krisberg, K. (2014). Anxiety: A normal response that can feel overwhelming. The Nation's Health: A Publication of the American Public Health Association. https://www.thenationshealth.org/ content $/ 44 / 2 / 24$

Kumara, J. W. N. T. N., \& Fasana, S. F. (2018). Work life conflict and its impact on turnover intention of employees: The mediation role of job satisfaction. International Journal of Scientific and Research Publications (IJSRP), 8(4), 478-484. https://doi.org/10.29322/IJSRP.8.4.2018.p7666

Kundnani, N., \& Mehta, P. (2014). Role of personality traits in balancing work-life. International Journal of Management Research \& Review, 4(7), 722-731.

Kurniawan, T. (2021). Kontribusi pendapatan ibu rumah tangga pengolah buah aren (Arenga Pinnata) dan kontribusinya terhadap pendapatan keluarga (Studi kasus Desa Sei Limbat kecamatan Selesai Kabupaten Langkat). Universitas Muhammadiyah Sumatera Utara.

Kurpisz, J., Mak, M., Lew-Starowicz, M., Nowosielski, K., Bieńkowski, P., Kowalczyk, R., Misiak, B., Frydecka, D., \& Samochowiec, J. (2016). Personality traits, gender roles and sexual behaviours of young adult males. Annals of General Psychiatry, 15, 28. https://doi.org/10.1186/s12991016-0114-2

Lunau, T., Bambra, C., Eikemo, T. A., van der Wel, K. A., \& Dragano, N. (2014). A balancing act? Work-life balance, health and well-being in European welfare states. European Journal of Public Health, 24(3), 422-427. https://doi.org/10.1093/eurpub/cku010

Marcinkus, W. C., Whelan-Berry, K. S., \& Gordon, J. R. (2007). The relationship of social support to the work-family balance and work outcomes of midlife women. Women in Management Review, 22(2), 86-111. https://doi.org/10.1108/09649420710732060

Meenakshi, S. P., Subrahmanyam, V., \& Ravichandran, K. (2013). The importance of work-life-balance. IOSR Journal of Business and Management, 14(3), 31-35.

Michalos, A. C. (Ed.). (2014). Encyclopedia of quality of life and well-being research. Springer Netherlands. 
Moyer, J. D., \& Hedden, S. (2020). Are we on the right path to achieve the sustainable development goals? World Development, 127, 104749. https://doi.org/10.1016/j.worlddev.2019.104749

Olivetti, C., Patacchini, E., \& Zenou, Y. (2020). Mothers, peers, and gender-role identity. Journal of the European Economic Association, 18(1), 266-301. https://doi.org/10.1093/jeea/jvy050

Padma, S., \& Reddy, M. S. (2013). Role of family support in balancing personal and work life of women employees. IJCEM International Journal of Computational Engineering \& Management, 16(3), 2230-7893.

Pandey, V. K., Shukla, T., \& Nanda, A. (2018). A study on impact of personality traits on work-life balance.

Rahmawati, A., Kusuma, A., \& Sumardjijati, S. (2019). Perempuan dalam industri kreatif Indonesia. Jurnal Ilmu Komunikasi, 2(1). https://doi.org/10.33005/jkom.v0i1.30

Sari, E. K., \& Zufar, B. N. (2021). Perempuan pencari nafkah selama pandemi COVID-19. Al-Mada: Jurnal Agama, Sosial, Dan Budaya, 4(1), 13-29. https://doi.org/10.31538/almada.v4i1.1106

Schieman, S., Glavin, P., \& Milkie, M. A. (2009). When work interferes with life: Work-nonwork interference and the influence of work-related demands and resources. American Sociological Review, 74(6), 966-988. https://doi.org/10.1177/000312240907400606

Shaffer, M. A., Sebastian Reiche, B., Dimitrova, M., Lazarova, M., Chen, S., Westman, M., \& Wurtz, O. (2016). Work and family-role adjustment of different types of global professionals: Scale development and validation. Journal of International Business Studies, 47(2), 113-139. https://doi.org/10.1057/jibs.2015.26

Shaleh, A. R. (2003). Pengaruh etos kerja dan locus of control terhadap sikap perempuan pada dirinya sebagai pekerja. Universitas Indonesia.

Shihab, N. (2019). Dari perempuan untuk perempuan: Catatan najwa. Youtube. https://www.youtube.com/watch?v=93FiM3tWT0g

Siregar, Y., Anogerajekti, N., \& Attas, S. G. (2021). Markobar oral tradition as local wisdom of the Mandailing community. ICNCS Proceeding UNS.

Smith-Hefner, N. J. (2007). Javanese women and the veil in Post-Soeharto Indonesia. The Journal of Asian Studies, 66(2), 389-420. https://doi.org/10.1017/S0021911807000575

Smith-Hefner, N. J. (2019). Islamizing intimacies: Youth, sexuality, and gender in contemporary Indonesia. University of Hawaii Press.

Smith, J., \& Gardner, D. (2007). Factors affecting employee use of work-life balance initiatives. New Zealand Journal of Psychology, 36(1), 3-12.

Swift, P., Cyhlarova, E., \& Goldie, I. (2014). Living with anxiety: Understanding the role and impact of anxiety in our lives. Mental Health Foundation.

Thompson, C. A., \& Prottas, D. J. (2006). Relationships among organizational family support, job autonomy, perceived control, and employee well-being. Journal of Occupational Health Psychology, 11(1), 100-118. https://doi.org/10.1037/1076-8998.10.4.100

Wahid, U., \& Lancia, F. (2018). Exchange of public and domestic roles of men and women in Indonesian television soap opera "Dunia Terbalik" (Analysis of Social Discourse M. K. Halliday). Advanced Science Letters, 24(10), 7141-7146. https://doi.org/10.1166/asl.2018.12427

Watkins, A. (2015). Problematic identities in women's fiction of the Sri Lankan diaspora. Brill Rodopi.

Wiasti, N. M. (2012). Redefinisi kecantikan dalam meningkatkan produktivitas kerja perempuan Bali, di Kota Denpasar. Piramida, 6(2), 1-22. 
World Bank. (2021). Labor force participation rate, female (\% of female population ages 15+) (modeled ILO estimate). The World Bank. https://data.worldbank.org/indicator/SL.TLF.CACT.FE.ZS

Yang, J. W., Suh, C., Lee, C. K., \& Son, B. C. (2018). The work-life balance and psychosocial well-being of South Korean workers. Annals of Occupational and Environmental Medicine, 30(1), 38. https://doi.org/10.1186/s40557-018-0250-z

Zakaria, M. F., \& Abdullah, A. H. (2018). The influence of big-five personality toward work- life balance: A teacher's perspective. International Journal of Education, Psychology and Counseling, 3(8), 2131.

Zimet, G. D., Dahlem, N. W., Zimet, S. G., \& Farley, G. K. (1988). The multidimensional scale of perceived social support. Journal of Personality Assessment, 52(1), 30-41. https://doi.org/10.1207/s15327752jpa5201_2 
This page has been intentionally left blank. 